\title{
Přehled systematických souhrnů studií: využití extraktu z Ginkgo biloba v léčbě mírného kognitivního poškození a demence
}

\author{
Hong-Feng Zhang, Li-Bo Huang, Yan-Biao Zhong, Qi-Hui Zhou, Hui-Lin Wang, Guo-Qing Zheng, Yan Lin
}

Úvod: Pokles kognitivních funkcí je výrazný sociální a zdravotní problém. Mezi stavy, které hodnotíme jako pokles kognitivních funkcí, počítáme: mírné kognitivní poškození ( $\mathrm{MCl}$ mild cognitive impairment) a demence. $\mathrm{MCl}$ je definováno jako mírné, ale zřetelné poškození kognitivních funkcí, zatímco u demence je postižení kognitivních funkcí již výrazné s dopady na fungování pacienta. Alzheimerova demence je nejčastější neurodegenerativní onemocnění, zatímco vaskulární demence se rozvijí na základě ischemického nebo hemoragického poškození, u smíšené demence je etiologie smíšená. V současnosti žije na světě 46 milionů lidís demencí, její výskyt stále narůstá. V roce 2050 je předpokládaný počet 131,5 milionů nemocných.

Léčba demence je symptomatická, v její léčbě jsou používána zejména kognitiva: inhibitory cholinesterázy (donepezil, galantamin, rivastigmin) a antagonisté NMDA receptorů (memantin). Z dalších preparátů využívaných $\checkmark$ léčbě tohoto onemocnění je extrakt z Gingko biloba (extrakt z GB).

Extrak z Ginkgo biloba (GB) je vyráběn z listů jinanu dvojlaločného a je užíván v léčbě řady onemocnění, jako jsou: kognitivní poruchy včetně demence, tinnitus, vertigo a řada dalších. Extrakt obsahuje směs flavonoidů, terpenů a glykosidů. Má antioxidační účinek, zvyšuje toleranci k hypoxii, zlepšuje realogické vlastnosti krve, ovlivňuje mikrocirkulaci a má vliv na řadu neurotrasmiterových systémů. Dále pozitivně ovlivňuje neuroplasticitu (tvorbu nových neuronů) a má neuroprotektivní účinek. K dispozici je větší množství preparátů, kde se extrakt liší podle získávání, nejvíce dat ohledně účinnosti a snášenlivosti je o extraktu EGb 761.

Článek se týká účinnosti a snášenlivosti extraktu z GB v léčbě $\mathrm{MCl}$, demence a v prevenci rozvoje kognitivního poškození.

Metodika: Do srovnání byly zařazeny systematické přehledy a metaanalýzy účinnosti extratu z Gingko biloba v prevenci a léčbě mírného kognitivního poškození a demence; byly vyhledány v šesti databázích do záŕi 2015 (Chinese Biological Medical Literature Database, Web of Science, Pubmed, Chinese Wanfang data, Chinese VIP information a Chinese National Knowledge Infrastructure). Při vyhledávání byla použita klíčová slova: "Gingko biloba" extract, EGb 761, pokles kognitivních funkcí, mírné kognitivní poškození, smíšená demence, Alzheimerova choroba, vaskulární demence, systematický přehled, metaanalýza.

Vstupní a vylučovací kritéria a výběr studií a sběr dat: Do přehledu byly zařazeny studie, které splňovaly následující kritéria: systematické přehledy nebo metaanalýzy hodnotící účinnost extraktu z GB v prevenci a léčbě mírného kognitivního poškození a demence (Alzheimerovy, vaskulární nebo smíšené). Všechny články byly přečteny a zhodnoceny dvěma nezávislými hodnotiteli, kteří se zaměřili na metodologickou kvalitu zařazených přehledů a studií (výběr, hodnocení, analýza dat, závěry). Tato kritéria splnilo deset prehledů.

Charakteristika zařazených studií: Zařazené studie a souhrny byly publikovány v letech 2010 až 2015, devět v angličtině, jeden souhrn v čínském jazyce. Bylo zařazeno deset systematických souhrnů s následujícími diagnostickými okruhy: Alzheimerova demence $(n=3)$, vaskulární demence $(n=1)$, oba typy demence: Alzheimerova a vaskulární $(n=2)$, dalši tři zahrnovaly Alzheimerovu, vaskulární a smíšenou demenci $(n=3)$, jeden souhrn se týkal mírného kognitivního poškození $(\mathrm{MCl})(\mathrm{n}=1)$. Kontrolované randomizované studie srovnávaly účinnost extraktu z GB s placebem a s preparáty používanými k léčbě kognitivních poruch a demence (kognitiva: inhibitory cholinesteráz, memantin a nootropika-piracetam) v léčbě pacientů s mírným kognitivním poškozením, vaskulární, Alzheimerovou a smíšenou demencí.

\section{Účinnost}

Prevence: Pouze dva systematické přehledy hodnotily prevenci poklesu kognitivních funkcí při léčbě extraktem z GB, výsledky nebyly signifikantní.

$\checkmark$ dalších studiích byl hodnocen vliv extraktu z GB v prevenci rozvoje Alzheimerovy demence (DeKosky et al., 2008; Vellas et al., 2012). Kvalita studií byla však problematická (statistické hodnocení výsledků, nízká compliance v léčbě...). Nicméně v jedné studii byl prokázán pozitivní vliv podávání extraktu z GB (EGb 761) v prevenci rozvoje Alzheimerovy demence, jednalo se o čtyr̆leté sledování (Vellas et al., 2012).

Mírné kognitivní poškození: Zde byl hodnocen vliv na každodenní aktivity (fungování) pacientů a kognitivní funkce. Nebyl nalezen signifikantní rozdíl mezi extraktem z GB v kombinaci s preparáty pro léčbu kognitivních poruch a demence (donepezil, rivastigmin, memantin, pira- 
cetam a injekční podání cerebroproteinu) a samotnými kognitivy. Ale v ovlivnění kognitivních funkcí byl samotný extrakt z GB a jeho kombinace s výše uvedenými preparáty (kognitivy) účinější, než jejich samotné podávání (Yang et al., 2016).

\section{Demence}

Celkový klinický stav: Dva systematické souhrny prokázaly vyšší účinnost extraktu z GB (EGb 761) ve srovnání s placebem (Wang et al., 2010; Gauthier et Schlaefke, 2014), účinnost EGb 761 byla závislá na dávce, vyšší dávky (240 mg denně) byly účinnější ve srovnání s nižším dávkováním (120mg denně) (Gauthier et Schlaefke, 2014)

Dále bylo hodnoce fungování pacientů v běžných denních aktivitách (ADL-Activities of daily living): $v$ jednom souhrnu byl prokázán pozitivní vliv extraktu z GB na denní fungování u pacientů s demencí (Tan et al., 2015); nicméně další souhrn tento účinek nepotvrdil (Weinmann et al., 2010). Do souhrnu nebyla zařazena řada posledních studií, které účinnost extraktu z GB na denní fungování pacientů s demencí potvrdily. Některé studie ukázaly souvislost účinku EGb 761 a věkem pacientů s demencí (Jiang et al., 2013), kdy došlo k signifikantnímu zlepšení denního fungování u mladších pacientů, tj. ve věku pod 75 let. Jednalo se o malý počet studií. Dalši práce však zlepšení v denním fungování potvrdily i u starší populace (Kasper, 2015). Rozdíl ve výsledcích může být opět vysvětlen výběrem studií, které byly zařazeny do srovnání a výběrem hodnoceného souboru pacientů.

Další dva systematické souhrny prokázaly výrazně vyšší účinnost vyšších dávek EGb 761 v ovlivnění běžného denního fungování pacientů, dávka 240 mg denně byla účinější než placebo (Jiang et al., 2013; Gauthier et Schlaefke, 2014). Byla prokázána účinnost i u nižších dávek 120 a 160 mg denně (Gauthier et Schlaefke, 2014), ale výsledek nebyl ve srovnání s vyšším dávkováním tak výrazný.

Kognitivní funkce: Byl prokázán pozitivní vliv podávání extraktu z GB na kognitivní funkce u pacientů s demencí (Weinmann et al., 2010; Tan et al., 2015), účinnost je však závislá na dávce tj. 240 mg denně (Jiang et al., 2013; Gauthier et Schlaefke, 2014) .

Neuropsychiatrické a behaviorální příznaky: Podávání extraktu z GB má pozitivní vliv na neuropsychiatrické príznaky včetně deprese. účinek byl opět závislý na dávce, signifikantně účinější byly dávky vyšší 240 mg denně EGb 761 ( $p<0,00001$ ) (Weinmann et al., 2010; Jiang et al., 2013; Gauthier et Schlaefke 2014; Tan et al., 2015).

\section{Alzheimerova demence}

Celkový klinický stav: Ve dvou systematických souhrnech byla prokázána účinnost extraktu z GB na celkový stav pacientů s Alzheimerovou demencí. Účinnost EGb 761 byla vyšší než placebo a srovnatelná s konvenčními preparáty používanými v léčbě demence (kognitiva) (Gauthier et Schlaefke, 2014; Yang et al., 2016).

Vliv na běžné denní fungování: Zde byla hodnocena účinnost EGb 761 na běžné denní fungování pacientů. EGb 761 byl účinný, jeho podávání vedlo ke zlepšení běžného denního fungování. Účinek byl opět závislý na dávce. Jako efektivní byly dávky vyšší, tj. 240 mg denně (Janssen et al., 2010; Weinmann et al., 2010; Yang et al., 2014; Tan et al., 2015).

Kognitivní funkce: Byl prokázán pozitivní vliv extraktu z GB na kognitivní funkce u pacientů s Alzheimerovou demencí (Weinmann et al., 2010; Tan et al., 2015).

Neuropsychiatrické a behaviorální příznaky: V posledním souhrnu publikovaném v roce 2015 byl prokázán pozitivní vliv EGb 761 na neuropsychiatrické príznaky u pacientů s Alzheimerovou demencí (Tan et al., 2015).

Kvalita života: $\vee$ souhrnu publikovaném v roce 2016 byla popsána vyšší účinnost extraktu z GB na kvalitu života ve srovnání s placebem. Jeho podávání ji zvyšovalo (Yang et al., 2016). Ve starším souhrnu z roku 2010 byly výsledky rozporuplné a ne tak zcela jednoznačné (Janssen et al., 2010).

\section{Vaskulární demence (VD)}

Dat týkajících se léčby vaskulární demence je o něco méně než u Alzheimerovy choroby. Extrakt z GB byl srovnatelně účinný u VD jako kognitiva (donepezil, memantin) v ovlivnění běžného denního fungování pacientů.

Kognitivní funkce: Bylo prokázáno zlepšení kognitivních funkcí (měřeno pomocí MMSE - Mini Mental State Examination) u pacientů s vaskulární demencí (Hu et al., 2013).

\section{Nežádoucí účinky a snášenlivost při léčbě extraktem z GB}

Osm systematických přehledů hodnotilo výskyt nežádoucích účinků při léčbě extraktem z GB a srovnávaly je s placebem (Janssen et al., 2010; Weinmann et al., 2010; Yang et al., 2011, 2016; Hu et al., 2013; Jiang et al., 2013; Gauthier et Schlaefke, 2014; Tan et al., 2015). Léčba extraktem z GB byla velmi dobře snášena; výskyt nežádoucích účinků byl srovnatelný s placebem. Ani výskyt závažných nežádoucích účinků se od placeba nelišil. Naopak užívání extraktu z GB v některých studiích ukázalo signifikantně nižší výskyt některých nežádoucích účinků, jako je bolest hlavy, závratě a tinnitus. Extrakt z GB nezpůsoboval změny krevního tlaku, hmotnosti, agitaci, neklid, nespavost, zažívací potíže a vyšší výskyt respiračních infekcí ve srovnání s placebem.

\section{Diskuze a závěr}

Jedná se o první publikovaný systematický přehled, který hodnotí účinnost a bezpečnost extraktu z GB v léčbě mírného kognitivního poškození a demence. Do souhrnu bylo zařazeno deset systematických přehledů, z čehož osm bylo hodnoceno jako vysoce kvalitních.

Úživání extraktu z GB vedlo ke zlepšení kognitivních funkcí a běžného denního fungování pacientů s demencí. Účinek je závislý na dávce. Výrazně vyšší efekt byl prokázán u vyšších dávek, tj. 240 mg denně. Léčba extraktem je velmi dobře snášená. Výskyt nežádoucích účinků je srovnatelný nebo nižší než při podávání placeba (týká se to výskytu závratí, vertiga, tinnitu, bolesti hlavy a anginy pectoris). $U$ těchto nežádoucích účinků byl nižší výskyt než u placeba.

Léčba extraktem z GB zlepšuje kognitivní funkce u pacientů s mírným kognitivním poškozením a demencí. Nebyl však prokázán vliv na běžné denní fungování u pacientů s MCI. Je zde však mírní pozitivní efekt předpokládaný, studie hodnotící tento účinek jsou starší a škály tehdy užívané nebyly tak citlivé na zhodnocení běžných denních aktivit.

Podávání extraktu z GB mělo pozitivní vliv na neuropsychiatrické a behaviorální príznaky u pacientů s demencí a u pacientů s Alzheimerovou demencí. Léčba zvyšuje kvalitu života pacientů. Nebyl prokázán vliv na progresi demence, ale nejsou k dispozici žádné studie, které by vliv extraktu z GB na progresi a patologii AD hodnotily.

Omezení (limitace): Je nutné uvést i omezení nebo limitace, které se tohoto přehledu studií týkají. Při získávání extraktu z GB jsou používány různé extrakční metody, proto se 
složení, účinnost a snášenlivost u různých typů extraktů z GB může mírně odlišovat. Je důležité podávání vhodného extraktu. Nejlepší výsledky jsou k dispozoci u extraktu EGb 761, a to i ve srovnání s ostatním extrakty z GB. Účinnost byla prokázána pouze u EGb 761 (Itil et al., 1996). Ačkoli naprostá většina zařazených souhrnů má velmi vysokou kvalitu, přece jenom metodika a kvalita starších studií je o něco nižší (týká se to použitých škál, výběru souboru pacientů, jeho velikosti...).

Důsledky pro budoucí výzkum a praxi: $\checkmark$ současně době není k dispozici žádný lék, který by fungoval jako účinná prevence rozvoje Alzheimerovy demence u zdravých jedinců. Nicméně v roce 2013 byla publikovaná studie, která hodnotila pozitivní vliv podávání EGb 761

\section{LITERATURA}

1. Amieva H, Meillon C, Helmer C, Barberger-Gateau P, Dartigues JF. (2013). Ginkgo bilobaextract and long-term cognitive decline: a 20-year follow-up population-basedstudy. PLoS ONE8:e52755. 10.1371/journal.pone.0052755 [PMC free article] [PubMed] [Cross Ref].

2. DeKosky ST, Williamson JD, Fitzpatrick AL, Kronmal RA, Ives DG, Saxton JA, et al. (2008). Ginkgo evaluation of memory (GEM) study investigators. Ginkgo biloba for prevention of dementia: a randomized controlled trial. JAMA 300, 2253-2262. 10.1001/jama.2008.683 [PMC free article] [PubMed] [Cross Ref].

3. Gauthier S, Schlaefke S. (2014). Efficacy and tolerability of Ginkgo biloba extract EGb $761^{\oplus}$ in dementia: a systematic review and meta-analysis of randomized placebo-controlled trials. Clin. Interv. Aging 9, 2065-2077. 10.2147/CIA.S72728 [PMC free article] [PubMed] [Cross Ref].

4. Gavrilova SI, Preuss UW, Wong JWM, Hoerr R, Kaschel R, Bachinskaya N, et al. (2014). Efficacy and safety of Ginkgo biloba extract EGb $761^{\oplus}$ in mild cognitive impairment with neuropsychiatric symptoms: a randomized, placebo-controlled, double-blind, multi-center trial. Int. J. Geriatr. Psychiatry 29, 1087-1095. 10.1002/gps.4103 [PubMed] [Cross Ref].

5. Grass-Kapanke B, Busmane A, Lasmanis A, Hoerr R, Kaschel R. (2011). Effects of Ginkgo bilobaspecial extract EGb 761 in Very Mild Cognitive Impairment (VMCI). Neurosci. Med. 2, 48-56. 10.4236/nm.2011.21007 [Cross Ref]. v prevenci kognitivního poklesu u nedementní, starší populace ve srovnání s jedinci, kteří EGb 761 neužívali. Je nutné však potvrdit i dlouhodobý účinek. V této studii byl hodnocen vliv EGb 761 a piracetamu v prevenci rozvoje kognitivního poklesu. Do studie byli zařazení nedementní pacienti ve věku nad 65 let $(n=3612)$, studie trvala 20 let (Amieva et al., 2013).

Jeden systematický přehled se zaměřil na účinnost podávání extraktu z GB u mírného kognitivního poškození, výsledky nebyly jednoznačné. Nicméně byly provedeny dvě kvalitní randomizované, placebem kontrolované studie, které prokázaly pozivitní vliv EGb 761 na zlepšení kognitivní funkcí a kvality života u pacientů s mírným kognitivním poškozením ve srovnání s placebem (Grass-Kapanke et al., 2011) a pozitiv-

6. Hu Q, Tu X, Zhang Y, Yang WY, Long J. (2013). Systemic review of Ginkgo biloba extract for vascular dementia. Liaoning J. Tradit. Chin. Med. 4, 683-686.

7. Itil TM, Eralp E, Tsambis E, Itil KZ, Stein U. (1996). Central nervous system effects of Ginkgo biloba, a plant extract. Am. J. Ther. 3, 63-73. 10.1097/00045391-199601000-00009 [PubMed][Cross Ref].

8. Janssen IM, Sturtz S, Skipka G, Zentner A, Velasco Garrido M, Busse R. (2010). Ginkgo bilobain Alzheimer's disease: a systematic review. Wien. Med. Wochenschr. 160, 539-546. 10.1007/s10354-010-0844-8 [PubMed] [Cross Ref].

9. Jiang L, Su L, Cui H, Ren J, Li C. (2013). Ginkgo biloba extract for dementia: a systematic review. Shanghai Arch. Psychiatry 25, 10-21. 10.3969/j.issn.1002-0829.2013.01.005 [PMC free article] [PubMed] [Cross Ref].

10. Kasper S. (2015). Phytopharmaceutical treatment of anxiety, depression, and dementia in the elderly: evidence from randomized, controlled clinical trials. Wien. Med. Wochenschr. 165, 217-228. 10.1007/s10354-015-0360-y [PubMed] [Cross Ref] 11. Tan MS, Yu JT, Tan CC, Wang HF, Meng XF, Wang C, et al. (2015). Efficacy and adverse effects of Ginkgo biloba for cognitive impairment and dementia: a systematic review and meta-analysis. J. Alzheimers Dis. 43, 589-603. 10.3233/JAD140837 [PubMed] [Cross Ref].

12. Vellas B, Coley N, Ousset PJ, Berrut G, Dartigues JF, Dubois B, et al. (2012). Long-term use of standardised Ginkgo biloba ní vliv na neuropsychiatrické příznaky (Gavrilova et al., 2014). První souhrny tyto studie nezahrnují.

Závěr: Současný přehled prokazuje jasnou účinnost extraktu z GB (EGb 761) v léčbě mírného kognitivního poškození a demence (Alzeheimerovy, vaskulární a smíšené). Je nutné zdůraznit i jeho velmi dobrou snášenlivost, kdy je výskyt nežádoucích účinků při léčbě EGb 761 srovnatelný a v některých případech i nižší než při podávání placeba.

účinnost byla prokázána pouze u extraktu EGb 761, je závislá na dávce, nejvyšší byla prokázána při podávání vyšších dávek, tj. 240 mg denně. Jeho současné podávání s kognitivy (donepezil, memantin) může vést i ke snížení výskytu nežádoucích účinků této léčby a tím ke zlepšení její snášenlivosti.

extract for the prevention of Alzheimer's disease (GuidAge): a randomised placebo-controlled trial. Lancet Neurol. 11, 851-859. 10.1016/S1474-4422(12)70206-5[PubMed] [Cross Ref]. 13. Wang BS, Wang H, Song YY, Qi H, Rong ZX, Wang BS, et al . (2010). Effectiveness of standardized Ginkgo biloba extract on cognitive symptoms of dementia with a six-month treatment: a bivariate random effect meta-analysis. Pharmacopsychiatry 43, 86-91. 10.1055/s-0029-1242817[PubMed] [Cross Ref] 14. Weinmann S, Roll S, Schwarzbach C, Vauth C, Willich SN. (2010). Effects of Ginkgo biloba in dementia: systematic review and meta-analysis. BMC Geriatr. 10:14. 10.1186/1471-231810-14 [PMC free article] [PubMed] [Cross Ref].

15. Yang G, Wang Y, Sun J, Zhang K, Liu J. (2016). Ginkgo biloba for mild cognitive impairment and Alzheimer's disease: a systematic review and meta-analysis of randomized controlled trials. Curr. Top. Med. Chem. 16, 520-528. 10.2174/156 8026615666150813143520 [PubMed] [Cross Ref].

16. Yang M, Xu DD, Zhang Y, Liu X, Hoeven R, Cho WC. (2014). A systematic review on natural medicines for the prevention and treatment of Alzheimer's disease with meta-analyses of intervention effect of ginkgo. Am. J. Chin. Med. 42, 505-521. 10.1142/S0192415X14500335 [PubMed][Cross Ref] 17. Yang Z, Li WJ, Huang T, Chen JM, Zhang X. (2011). Meta-analysis of Ginkgo biloba extract for the treatment of Alzheimer's disease. Neural Regen. Res. 6, 1125-1129. 10.3969/j. issn.1673-5374.2011.15.001 [Cross Ref]. 